\title{
Predicting Children's Behavior Problems from Temperamental Attributes and Maternal Responsiveness During Preschool Period
}

\author{
Jinna Chung \\ Department of Early Childhood Education, Yong-In Songdam University, Yongin, Korea \\ 3 세의 기질 특성과 어머니 반응성이 5 세의 문제행동 발달에 미치는 영향 \\ 정진나 \\ 용인송담대학교 유아교육과
}

Objective: This study aimed to examine the longitudinal relations of children's temperamental attributes (i.e., emotionality, activity, and sociability) and maternal responsiveness to overall and specific externalizing/internalizing behavior problems during the preschool period.

Methods: Data $(N=1,438)$ from the 4th and 6th wave of Panel Study on Korean Children (PSKC) were used in a series of hierarchical regression analyses. The analyses were conducted to determine the additive and interactive effects of maternal responsiveness and temperamental attributes of children at the age of 3 years on the broadband and narrowband scales of their behavior problems at the age of 5 years.

Results: Overall, results confirmed the additive and interactive effects of maternal responsiveness and temperamental attributes on the levels of different domains of behavior problems. Examination of the interactive effects showed that maternal responsiveness was more strongly related to some behavior problems for temperamentally vulnerable children as compared to children with less temperamental vulnerabilities.

Conclusion: The findings suggested that the beneficial effects of positive parenting on the development of behavior problems might be more pronounced for temperamentally vulnerable than for less vulnerable children.

Keywords: temperament, externalizing behavior problems, internalizing behavior problems, maternal responsiveness, preschool children

\begin{abstract}
서론
3세에서 5세 유아기는 환경에 보다 의존적이었던 영아기에서 벗어나 자율성을 크게 발달시켜나가는 발달의 주요 전환기로, 이 시기 유아들은 수많은 발달과업에 직면해 있다. 이러한 발 달적 전환기에 문제행동이 자리 잡으면 문제는 보다 장기화

Corresponding Author: Jinna Chung, Department of Early Childhood Education, Yoing-In Songdam University, 61 Dongbu-ro, Cheoin-gu, Gyeonggi-do, Korea

E-mail: jnchung@ysc.ac.kr
\end{abstract}

될 위험이 커지고, 이후 학업실패, 대인관계 갈등, 비행과 같은 수많은 부적응 문제를 야기할 가능성도 증가한다(Campbell, 1995; Moffitt, 1990).

유아기에 나타난 심각한 문제행동은 종종 이후에도 지속된 다고 알려져 있다. 유아기 문제행동은 청소년기까지 비교적 높은 안정성을 보일 뿐 아니라 나이가 들면서 전체 아동의 문

(C)The Korean Association of Child Studies

This is an Open Access article distributed under the terms of the Creative Commons Attribution Non-Commercial License (http:// creativecommons.org/licenses/by-nc/4.0) which permits unrestricted noncommercial use, distribution, and reproduction in any medium, provided the original work is properly cited. 
제행동 평균 수준이 감소될 때조차 개별 아동의 상대적 순위 는 거의 동일하게 유지되는 것으로 나타난다(Campbell, 1995; Mesman, Bongers, \& Koot, 2001). Moffitt (1990)도 높은 수준의 문제행동을 지닌 청소년들은 영유아기부터 이러한 문제를 나 타낸다는 것을 보여주었다. 물론 유아들이 보이는 문제행동의 상당수는 정상적 발달과정을 반영하는 경우도 많다. 그러나 유아들의 10-15\%는 경계할만한 심각한 수준의 문제행동을 보인다는 사실에는 주목할 필요가 있다(Campbell, 1995; Lee, Shin, Chun, \& Park, 2004).

정신병리에서 아동의 문제행동에 대한 차원적 접근은 다 양한 문제행동 항목들에 대한 요인분석 결과를 바탕으로 한 다. 이 접근에서는 문제행동이 크게 외현화(externalizing) 문 제와 내재화(internalizing) 문제라는 두 개의 넓은(broadband) 요인으로 구성되며, 이 넓은 요인은 다시 그 하위의 좁은 (narrowband) 요인들로 구성된다는 일종의 위계구조를 가정한 다(Achenbach, Ivanova, Rescorla, Turner, \& Althoff, 2016). 따라 서 넓은 요인 점수는 그에 속한 좁은 요인 척도들의 점수를 합 산함으로써 산출된다. 이러한 위계구조는 아동을 특정 문제유 형으로 범주화하는 대신 여러 척도 점수들에 대한 프로파일을 제공함으로써 개별 아동의 독특한 문제행동 패턴을 알게 해준 다는 장점이 있다. 그동안 외현화, 내재화라는 두 축이 임상 측 면에서 유용한 넓은 요인 모델을 제공해주었다는 것은 명백하 다. 그러나 넓은 요인 척도와 더불어 좁은 요인 척도를 함께 살 펴보는 것 또한 아동 문제행동의 원인이나 결과를 파악하거나 중재계획을 수립함에 있어 보다 유용한 정보를 제공해줄 수 있다(Achenbach et al., 2016).

외현화 문제행동은 공격행동, 비행, 충동성과 같이 통제되 지 않고 외부로 표출되는 행동을 일컫는다. 내재화 문제행동 은 불안, 위축 같이 내부로 향하는 스트레스나 갈등 경험을 뜻 한다. 외현화 문제는 보통 3-5세 사이에 출현하는데, 주로 공 격적이고 비순응적 행동으로 나타나며 또래 거부나 학습부 진 같은 부적응 문제와 관련된다(Campbell, Spieker, Burchinal, Poe, \& NICHD Early Child Care Research Network, 2006). 내재 화 문제는 보다 이후인 학동기 후반이나 청소년기에 가장 높 은 수준으로 나타나지만, 그 초기 징후는 유아기에도 찾아볼 수 있다(Gartstein, Putnam, \& Rothbart, 2012).

그동안 연구자들은 주로 유아의 외현화 문제에 많은 관심 을 기울여 왔으며, 상대적으로 내재화 문제에 대한 관심은 제 한적이었다. 이는 아마도 외현화 문제가 겉으로 드러나기 쉽 고 부모나 교사들에게 명백한 위험요소로 보였기 때문일 수 있다. 그러나 외현화 문제와 마찬가지로 내재화 문제도 발
달에 심각한 영향을 미친다. 선행연구에 따르면 유아의 내재 화 문제는 이후 학동기나 청소년기의 문제행동과 우울증의 발생 위험을 높인다(Mesman et al., 2001; Putnam, Sanson, \& Rothbart, 2002). 따라서 아동의 문제행동을 효과적으로 예방 하기 위해서는 외현화 문제와 내재화 문제 둘 다를 함께 고려 할 필요가 있다.

문제행동의 발달경로에는 다양한 환경적 요인들과 아동내 적인 유전적, 심리적 요인들이 끓임없이 서로 상호작용한다. 이러한 요인들 중 환경요인으로는 부모양육이, 그리고 아동내 적 요인으로는 기질이 가장 중요한 변인으로 주목받아 왔다. 특히 어린 아동들에게 부모양육은 가장 중요한 환경요인 중 하나일 것이다. 지금까지 많은 발달 이론가들과 연구자들도 어린 아동의 요구에 반응하는 양육자의 민감하고 따뜻한 태도 가 아동의 적응적 발달에 결정적 역할을 한다는 사실을 강조 해왔다(Carlson, 1998; Maccoby \& Martin, 1983). 아동의 문제 행동 발달과 관련하여 그러한 위험을 높이는 부모양육의 주요 측면은 적대적이고 둔감한 양육행동과 부정적 통제사용으로 알려져 있다(Doh, Shin, Park, Kim, \& Kim, 2014; Putnam et al., 2002). 그러나 이러한 부모양육의 영향력은 아동내적 특성인 기질과의 관계 속에서 보다 명확히 이해될 수 있다. 아동의 기 질은 부모양육에 영향을 미침과 동시에 부모양육 또한 아동의 기질에 영향을 미치며, 이러한 밀접한 상호관계는 문제행동과 관련한 특정 발달경로를 다른 방향으로 변화시킬 수 있기 때 문이다(Rothbart \& Bates, 2006).

기질은 아동이 환경과 상호작용하는 방식에서의 개인차 를 의미하는 것으로 강한 생물학적 기반을 지닌다고 가정된다 (Goldsmith et al., 1987). 기질의 개인차는 출생 직후부터 나타 나고 이후 전생애에 걸쳐 비교적 안정적으로 유지된다고 알 려져 있다. 그러나 기질이 생물학적 기반을 지니는 안정적 특 질이라고 해서 기질이 변하지 않는다는 의미는 아니다. 기질 안정성은 영아기에 크게 증가하여 3세 무렵 가장 높은 수준으 로 나타나지만 이후에는 안정성이 더 이상 증가하지 않고 유 아기보다 다소 낮은 수준으로 유지된다(Roberts \& DelVecchio, 2000). 이러한 사실은 기질이 생의 초기에는 유전에 기초하지 만 이후 환경과 경험에 의해 변화될 수 있다는 것을 의미한다.

최근의 기질 연구자들은 기질을 구성하는 그 하위차원 에 주목한다. 이러한 접근에는 여러 이론적 모델이 있고 이 들마다 기질 차원의 명칭이나 정의도 다양하다. 대표적인 차 원적 접근 중 하나인 Buss와 Plomin (1984)의 모델은 기질의 하위차원으로 정서성(emotionality), 활동성(activity), 사회성 (sociability), 수줍음(shyness)을 가정한다. 정서성은 스트레스 
나 분노와 같은 부정적 정서를 쉽게 경험하는 성향을, 활동성 은 빠르고 활발한 움직임을 선호하는 성향을 의미한다. 사회 성은 타인들과 함께 있는 것을 선호하는 성향을, 수줍음은 낮 선 사람 앞에서 긴장하고 불안해하며 사회적 상황을 회피하려 는 성향을 의미한다. 한편 Mervielde와 Asendorpf (2000)에 따 르면, Buss와 Plomin의 정서성 차원은 또 다른 대표적 모델인 Thomas와 Chess (1977), 그리고 Rothbart (1989) 모델에서의 부 정적 정서차원과 유사하다. 그리고 활동성 차원과 사회성/수 줍음 차원은 Thomas와 Chess 모델에서는 각각 활동 수준 차원 과 억제(inhibition) 차원과 유사하며, Rothbart 모델에서는 둘 다 외향성(surgency) 차원과 서로 중첩되는 부분이 많다.

기질에 대해 적용된 이론적 모델이 무엇이든 간에, 선행 연구들은 횡단적으로도 종단적으로도 유아기 기질과 문제 행동의 관련성을 보여주었다. 선행연구 대다수가 주로 외현 화 문제행동만 다루었다는 한계가 있지만 관련 자료를 종합 하면 다음과 같다. 먼저 유아의 높은 정서성(또는 부정적 정 서) 기질은 이후 외현화 문제와 내재화 문제를 모두 증가시키 는 위험요인으로 보고되었다(Gartstein et al., 2012; Y. S. Kim \& Kwak, 2016; Han \& Lee, 2016). 반대로, 높은 사회성 기질 은 모든 유형의 문제행동을 감소시키는 보호요인으로 보고되 었다(Putnam et al., 2002; Smith \& Prior, 1995). 한편 활동성 기 질에 대한 결과는 외현화 문제와 내재화 문제에서 서로 엇갈 리는데, 유아의 높은 활동성 기질이 대체로 외현화 문제를 증 가시키는 반면 내재화 문제는 감소시키는 것으로 나타났다 (Mathiesen \& Prior, 2006).

발달의 교류모델(transactional model)은 발달에 영향을 미치 는 요인으로 아동 개인의 특성과 주변 환경 간 상호작용을 중 시한다(Sameroff, 1975). 유아기 문제행동의 발달도 아동의 기 질 특성과 양육환경 간 관계 속에서 이해될 필요가 있다. 최근 의 연구들에서도 기질과 부모양육의 상호작용 모델을 적용하 여 문제행동의 발달을 설명하려는 시도가 눈에 띄게 증가하고 있다(Belsky, 2005; Rothbart \& Bates, 2006). 선행 종단연구로는 Belsky, Hsieh와 Crnic (1998)이 영유아기 동안 초기의 양육경 험이 이후의 외현화 문제행동에 미치는 영향력의 정도가 아동 의 기질 특성에 따라 달라진다는 것을 보여준 사례를 들 수 있 다. 이 연구에서는 영아기에 부정적 정서 기질을 보였던 아동 들은 그렇지 않은 아동들에 비해 부정적 양육을 경험한 경우 3 세 때 높은 수준의 외현화 문제를 나타내는 경향이 큰 것으로 나타났다. 그러나 이러한 아동들이 긍정적 양육을 경험한 경 우에는 3 세 시기 외현화 문제 수준이 보다 크게 감소하는 것으 로 나타났다. 이와 유사하게, Bradley와 Corwyn (2008), 그리고
Stright, Gallagher와 Kelly (2008)도 영아기에 까다로운 기질을 나타낸 아동일수록 부모양육이 학동기 초반의 외현화 문제행 동이나 적응적 발달(학업능력, 사회적 기술 등)에 미치는 영향 력이 보다 크다는 것을 보여주었다.

문제행동의 발달에 미치는 기질과 부모양육의 이러한 상호 작용 효과는 Belsky (2005)가 제안한 차별적 민감성(differential susceptibility) 가설을 통해 보다 명확히 설명될 수 있다. 이 가 설에 따르면, 아동 개인이 지닌 기질 특성에 따라 부모양육이 발달에 미치는 효과가 다를 수 있다. 즉, 발달에 취약한 기질 (예: 부정적 정서, 까다로운 기질)을 지닌 아동일수록 부정적 양육경험은 보다 부정적인 발달성과를 야기하지만, 다른 한편 으로 긍정적 양육경험은 보다 긍정적인 발달성과를 야기할 수 있다는 것이다. Rothbart와 Bates (2006)도 아동발달에 대한 기 질과 부모양육의 상호작용 모델을 강조하며, 아동의 기질 특 성과 부모양육은 보다 나은 발달성과를 야기하기 위해 서로가 서로에게 크게 의존한다는 점을 간과해서는 안 된다고 주장하 였다. 아동발달에서 조기중재의 중요성을 고려하면, 취약한 기질의 아동일수록 이를 극복하고 적응적 발달을 이루기 위해 서 긍정적 양육경험을 보다 크게 필요로 한다는 사실에 주목 할 필요가 있다(Belsky, 2005; Bradley \& Corwyn, 2008).

결론적으로, 기질 안정성이 가장 높다고 알려진 3 세 무렵 유아의 기질 특성과 부모양육은 학령기로 전환되기 바로 전 시기인 5세 무렵 나타나는 다양한 유형의 문제행동을 각각 독 립적으로 예측함과 동시에 함께 상호작용해서도 예측할 것으 로 가정해 볼 수 있다. 무엇보다 발달 초기 부모양육이 이후 문 제행동 발달에 미치는 효과는 유아가 지닌 기질 특성에 따라 그 효과 정도가 다를 수 있을 것이다. 그러나 이러한 결론에는 일부 제한이 따른다. 첫째, 유아기 동안 기질, 부모양육, 문제 행동 간 관계에 대한 종단자료가 비교적 드물다는 것이다. 선 행연구 대다수가 횡단연구였다는 사실은 변인들 간 관계의 방 향성에 대한 결론이 명확치 않다는 한계를 지닌다. 특히 기질 과 문제행동 간 관계에 대해서는, 이 둘이 별개가 아닌 공통의 성격특질을 반영하는 것으로 각각을 재는 문항들도 상당부분 중첩된다는 논란이 있다(Nigg, 2006). 둘째, 선행연구 대다수 가 주로 문제행동의 넓은 요인, 그 중에서도 주로 외현화 문제 에 주목했기 때문에 유아기에 나타나는 다양한 유형의 문제행 동 발달에 대한 구체적인 정보가 제한적이라는 것이다.

이에 따라 본 연구는 기질변인으로 정서성, 활동성, 사회성 차원을 포함하고, 문제행동 변인으로 넓은 요인과 좁은 요인 척도를 모두 포함하여 3-5세 유아기 동안 초기의 기질 특성과 어머니의 반응적 양육태도가 후반의 문제행동 발달에 미치는 
영향을 보다 구체적으로 밝히고자 하였다. 이를 위해 3 세의 서 로 다른 기질 특성과 어머니 반응성이 5 세의 다양한 문제행동 영역에 미치는 독립적 영향력을 살펴보고, 특정 기질 특성이 어머니 반응성과 어떻게 상호작용하여 문제행동 영역에 영향 을 미치는지 살펴보고자 하였다. 특히 기질과 어머니 반응성 의 상호작용 효과와 관련해서는, 유아의 기질 특성이 어머니 반응성과 문제행동 간 종단관계를 조절할 것으로 가정하였다. 연구문제는 다음과 같다.

\section{연구문제 1}

3 세의 기질 특성과 어머니 반응성, 그리고 5 세의 문제행동 영 역 간 관계는 어떠한가?

\section{연구문제 2}

3 세의 기질 특성과 어머니 반응성이 5 세의 문제행동 영역에 미치는 영향은 어떠한가?

2-1. 3세의 기질 특성과 어머니 반응성이 5 세의 전반적 외 현화 문제행동과 그 하위영역에 미치는 독립적 영향력과 상호작용 효과는 어떠한가?

2-2. 3 세의 기질 특성과 어머니 반응성이 5 세의 전반적 내재화 문제행동과 그 하위영역에 미치는 독립적 영향력과 상호작용 효과는 어떠한가?

\section{연구방법}

\section{연구대상}

본 연구는 육아정책연구소의 한국아동패널(Panel Study on Korean Children [PSKC]) 4차년도(2011년)와 6차년도(2013년) 자료를 사용하였다. 한국아동패널은 2008년도에 출생한 신생 아 가구 2,150가구를 전체 표본으로 구축한 이래로 매해 아동 발달, 부모양육, 가족 특성 등을 추적 조사한 자료를 제공해오 고 있다. 4 차년도에는 1,754 가구가 참여하였으며, 6차년도에 는 1,662 가구가 참여하였다. 본 연구에서는 이 중 연구변인들 에 대해 모두 응답한 가구를 대상으로 하였으며, 최종적으로 1,438 가구의 자료가 분석에 포함되었다.

먼저 연구대상 유아들은 남아가 734명(51\%), 여아가 704 명(49\%)이었다. 유아들의 평균월령은 4차년도(Time 1)에
$38.71(S D=1.44)$ 개월, 6차년도(Time 2)에 $62.66(S D=1.32)$ 개개월이었다. 참고로, 연구대상 유아들(Time 2)의 문제행동 수준이 전반적으로 어떠한지 알아보고자 유아행동평가척도 (K-CBCL 1.5-5)의 위험수준 기준점(cutoff score)에 따른 유아 들의 분포를 살펴보았다. K-CBCL 매뉴얼에 따르면 T점수 60 이상의 유아들은 임상서비스를 필요로 할 가능성이 큰 준임상 집단(T점수 60-63)과 임상집단(T점수 64이상)으로 분류된다. 유아들의 T점수 분포를 살펴본 결과, 외현화 문제행동 $(M d n=$ 47.00, Range $=31-84)$ 과 내재화 문제행동 $(M d n=48.00$, Range = 31-88) 모두에서 대다수 유아들이 정상집단(T점수 59이하) 에 속하는 것으로 나타났다. 그러나 동시에, 외현화 문제행동 에서 $9.4 \%$ 의 유아들이, 내재화 문제행동에서 $13.3 \%$ 의 유아들 이 위험군에 해당되는 준임상 및 임상집단에 속한 것으로 나 타났다.

다음으로 연구대상 어머니들의 평균연령은 Time 1을 기준 으로 33.82세 $(S D=3.66)$ 였으며, 최종학력은 대학졸업이 945 명(55\%)으로 가장 많고 고졸 409명(28\%), 대학원졸업 71명 $(5 \%)$, 중졸이하 10 명 $(0.8 \%)$ 순이었다. 또한 가구소득 $(M d n=$ 380 만원)은 $301-500$ 만원인 가구가 591가구(41\%)로 가장 많 고, 300 만원 이하가 496 가구(35\%), 501만원 이상이 351가구 (24\%) 순이었다.

\section{연구도구}

\section{기질}

유아 기질은 Buss와 Plomin (1984)의 Emotionality, Activity, and Sociability-Temperament Survey for Children-Parental Ratings (EAS)를 사용하여 측정되었다. 이 도구는 1 세에서 9세까지 사 용가능한 도구로, 정서성(emotionality), 활동성(activity), 사회 성/수줍음(sociability/shyness)의 3 개 척도를 포함한다. 주 양육 자가 1점(전혀 그렇지 않다)부터 5점(매우 그렇다)까지 5점 리 커트 척도로 응답하도록 되어 있으며 총 20문항으로 구성되 어있다. 정서성 척도(5문항)는 유아가 부정적 정서를 많이 나 타내는 성향을 측정한다(예: “우리 아이는 쉽게 기분이 나빠 진다.”, “우리 아이는 화가 났을 때 격하게 반응한다.”). 활동성 척도(5문항)는 유아가 빠르고 동적인 움직임을 선호하는 성향 을 측정한다(예: “우리 아이는 항상 끊임없이 움직인다.", “우 리 아이는 아침에 일어나자마자 열심히 움직인다.”). 사회성/ 수줍음 척도(10문항)는 유아가 타인과 잘 어울리며 덜 수줍어 하는 특성을 측정한다(예: "우리 아이는 사람들과 함께 있기를 
좋아한다.”, “우리 아이는 수줍음을 타는 편이다.”). 척도의 높 은 점수는 각 기질 차원의 수준이 높다는 것을 의미한다. 정서 성, 활동성, 사회성 척도에 대한 Cronbach's $\alpha$ 는 각각 .73, .79, .83 이었다.

\section{어머니 반응성}

어머니 반응성은 The Parental Style Questionnaire (PSQ; Bornstein et al., 1996)로 측정되었다. PSQ는 부모용 질문지로, 그 하위척도로는 사회적 상호작용 유형(social interaction), 가 르치는 유형(didactic/material stimulation), 한계설정 유형(limit setting)이 있다. 본 연구는 이중에서 부모의 반응적 양육태도 와 관련된 사회적 상호작용 척도를 사용하였다. 사회적 상호 작용은 부모와 자녀 간 상호작용의 질을 의미하는 것으로, 자 녀에 대한 부모의 반응성과 온정성을 포함하는 개념이다. 따 라서 사회적 상호작용 척도는 반응적이고 온정적인 부모양 육을 측정하는 총 9문항으로 구성되어있다(예: "나는 우리 아 이가 힘들어하거나 불편해하면 즉시 적절히 반응한다.", "나 는 우리아이에게 긍정적이고 애정적이며 따뜻한 관심을 보인 다.”). 각 문항은 1점(전혀 그렇지 않다)부터 5점(매우 그렇다) 까지 5점 리커트 척도로 응답하도록 되어있으며, 높은 점수는 보다 반응적인 양육을 의미한다. 척도의 Cronbach's $\alpha$ 는 .87이 었다.

\section{문제행동}

유아의 문제행동은 Achenbach와 Rescorla (2000)의 유아행동 평가척도(Child Behavior Checklist for Ages 1.5-5)를 Oh와 Kim (2008)이 한국판으로 표준화한 K-CBCL 1.5-5를 사용하여 측 정되었다. 이 척도는 1 세 반에서 5 세 유아를 대상으로 부모가 평정하도록 제작된 척도다. 척도는 외현화 문제행동과 내재화 문제행동이라는 2개의 넓은 요인 척도(broadband scales)와, 그 하위의 보다 특수한 6 개의 좁은 요인 척도(narrowband scales) 를 포함한다. 외현화 문제행동은 유아의 주의력 문제나 공격 적 행동과 같이 통제가 부족한 행동을, 내재화 문제행동은 소 극적이고 불안해하거나 위축되는 등 지나치게 억제된 행동을 의미한다. 본 연구에서는 외현화 문제행동( 24 문항)에 해당하 는 주의집중 문제와 공격행동의 2 개 하위요인과, 내재화 문제 행동(36문항)에 해당하는 정서적 반응성, 불안/우울, 신체증 상, 위축의 4 개 하위요인을 재는 총 60 문항을 사용하였다. 주 의집중 문제( 5 문항)는 주의력 부족이나 과잉 활동성과 관련
된 문항들로 구성되고, 공격행동(19문항)은 타인에 대한 신체 적 공격과 기물 파괴와 같은 행동적 측면과, 쉽게 좌절하며 반 항적이 되고 분노발작을 하는 것 같은 정서적 측면과 관련된 문항들로 구성된다. 정서적 반응성(9문항)은 낮선 상황에 대 한 불안, 일상의 변화에 대한 저항과 짜증, 걱정 등 정서적 안 정성과 관련된 문항들로 구성되며, 불안/우울(8문항)은 지나 치게 예민하고 불안해하거나 전반적으로 슬퍼 보이는 등 부정 적 감정과 관련된 문항들로 구성된다. 신체증상(11문항)은 뚜 렷한 의학적 원인 없이 나타나는 배변문제, 두통, 배않이, 구 토 같은 신체적 불편감과 물건이 제자리에 있지 않으면 견디 지 못하는 등의 불분명한 예민함과 관련된 문항들로 구성된 다. 위축(8문항)은 해당 연령에서 기대되는 것보다 위축되고 어린 행동, 애정 표현이나 놀이에 대한 무관심과 관련된 문항 들로 구성된다. 모든 문항은 0점(전혀 해당되지 않는다)부터 2 점(자주 그런 일이 있거나 많이 그렇다)까지 3점 리커트 척도 로 응답하게 되어있다. 원점수가 본 분석에 사용되었으며, 각 하위 척도의 점수가 높을수록 그러한 문제행동 수준이 높다는 것을 의미한다. Cronbach's $\alpha$ 는 외현화 문제 총점과 내재화 문 제 총점 둘 다. 88 로 동일하였고, 주의집중 문제 .62, 공격행동 .87 , 정서적 반응성 .74 , 불안/우울 .71 , 신체증상 .55 , 위축 .65 이었다. 참고로, 이러한 $\alpha$ 값은 최근 24 개 사회에 걸쳐 $\mathrm{CBCL}$ 1.5-5의 모든 하위척도 $\alpha$ 값을 비교분석한 Rescorla 등(2011)의 연구결과와 거의 일치한다. 척도 신뢰도에 대한 일반적 기준 (DeVellis, 1991; Nunnally \& Bernstein, 1994)에 의하면, 본 연구 의 신체증상 척도의 $\alpha$ 값은 Rescorla 등의 연구에서와 같이 최 저 수용한계(.60)에 미치지 못했다. 그러나 Rescorla 등의 제안 을 참고하고, 해당 척도가 단일 요인을 측정하는 것으로 가정 되는 표준화 척도임을 고려하여 분석에 포함하였다.

\section{통제변인}

유아 성별, 어머니 학력, 가구소득을 통제변인으로 고려하였 다. 이는 선행연구(Kang \& Oh, 2011; Putnam et al., 2002)에서 본 연구의 변인들 간 관계에 영향을 미칠 수 있다고 제안되었 기 때문이다. 성별은 더미코딩 하였고 $(0=$ 여아, $1=$ 남아 $)$, 어 머니 학력은 학력수준을 교육 햇수로 변환하여(초졸[6년] 박 사졸[21년]) 변인을 구성하였다. 가구소득은 근로/사업 소득, 자산소득 등을 모두 합해 가구소득 전체의 합을 구한 후 이를 10 개의 범주로 변환하여(0 [0원] 9 [1500만원 이상]) 변인을 구성하였다. 
Table 1

Correlations, Mean Scores, and Standard Deviations for Predictors and Outcome Variables

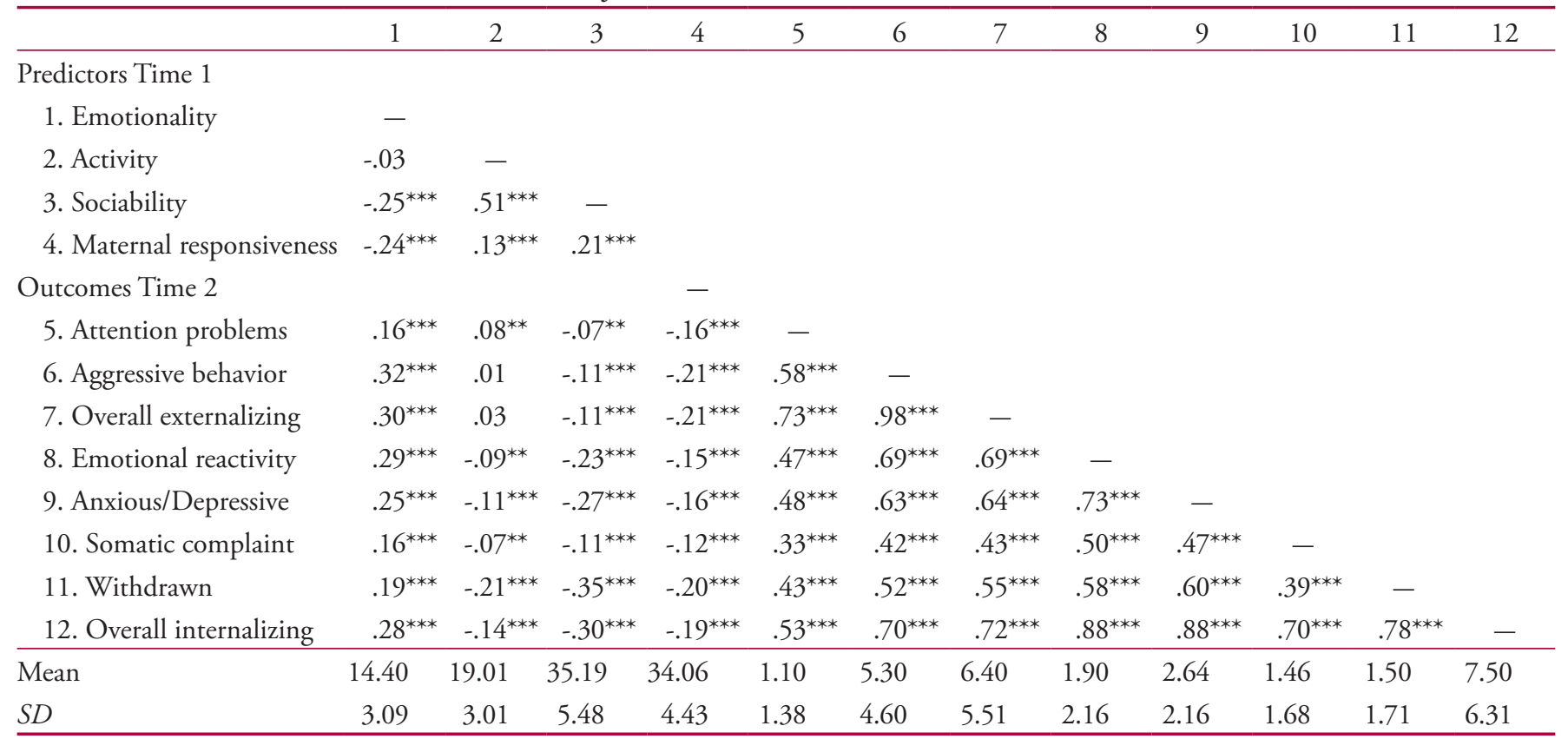

Note. $N=1,438$.

${ }^{* *} p<.01 .{ }^{* * *} p<.001$.

\section{자료분석}

자료에 대해 다음과 같은 순서로 분석을 진행하였다. 먼저, 본 연구의 주요 변인들 간 상관관계와 평균 및 표준편차를 제시 하였다. 다음으로, 3 세(Time 1)의 기질과 어머니 반응성이 5세 (Time 2)의 각 문제행동 영역에 미치는 주효과(독립적 영향력) 와 상호작용 효과를 알아보기 위해 일련의 위계적 다중 회귀 분석을 실시하였다. 위계적 회귀분석은 회귀방정식 마지막 단 계에 상호작용 항을 포함시킴으로써 특정 연속 변인의 조절효 과를 검증하기에 적절한 통계분석 방법이다(Baron \& Kenny, 1986). 이 분석은 종속변인에 대한 예측변인들의 고유한 영향 력을 순서대로 파악할 수 있게 해줄 뿐 아니라 마지막에 투입 된 곱항과 그 상호작용이 먼저 투입된 예측변인들 이상으로 종속변인에 추가적인 기여를 하는지 보여줄 수 있다. 따라서 기질의 조절효과는 특정 기질차원과 어머니 반응성 간 상호 작용 효과를 통해 확인될 수 있다. 모든 통계 분석에는 PASW 18.0 (SPSS Inc., Chicago, IL)을 사용하였다.

\section{연구결과}

본 분석을 실시하기에 앞서 통제변인에 대한 예비분석을 실시
한 결과, 유아 성별, 어머니 학력, 가구소득은 모두가 대체로 본 연구의 주요 변인들 상당수와 유의한 상관을 보였다. 따라 서 회귀분석에서 이들 변인을 통제변인으로 고려하는 것이 적 절한 것으로 나타났다.

\section{주요 변인들 간 상관관계}

주요 변인들 간 상관관계와 평균, 표준편차가 Table 1에 제시 되어 있다. 표를 보면 거의 모든 변인들 간 상관이 유의하게 나 타났다는 것을 알 수 있다. 우선 Time 1의 예측변인들 간 상관 을 살펴보면, 기질 변인들끼리의 상관은 '정서성 vs. 활동성' 만 제외하고 모두 유의하였다. '정서성 vs. 사회성'은 부적상관 $(r=-.25, p<.001)$ 을, '활동성 vs. 사회성'은 정적상관 $(r=.51, p$ <.001)을 나타냈다. 어머니 반응성은 정서성 기질과는 부적상 관을 $(r=-.24, p<.001)$, 활동성 기질 및 사회성 기질과는 정적 상관을 나타냈다 $(r s=.13, .21, p s<.001)$. Time 2 의 종속변인들 끼리의 상관은 모든 상관이 유의하였다(all $p s<.001)$.

모든 변인들 간 상관을 종합해서 살펴보면, 정서성 기질은 어머니 반응성과 유의한 부적상관을, 문제행동의 모든 영역 들과는 유의한 정적상관 $(r s=.16 \sim .32, p s<.001)$ 을 나타냈다. 이는 3 세에 정서성 기질이 높은 유아일수록 보다 낮은 어머니 
Table 2

Regression Model Predicting Children's Externalizing Behaviors

\begin{tabular}{|c|c|c|c|c|c|c|}
\hline \multirow[b]{2}{*}{ Variable } & \multicolumn{2}{|c|}{ Attention problems } & \multicolumn{2}{|c|}{ Aggressive behavior } & \multicolumn{2}{|c|}{ Overall externalizing } \\
\hline & $B(S E B)$ & $\beta$ & $B(S E B)$ & $\beta$ & $B(S E B)$ & $\beta$ \\
\hline \multicolumn{7}{|l|}{ Step 1} \\
\hline Sex & $.36(.07)$ & $.13^{* * *}$ & $.93(.24)$ & $.10^{* * *}$ & $1.29(.29)$ & $.12^{* * *}$ \\
\hline Maternal education & $-.06(.02)$ & $-.08^{* *}$ & $.00(.06)$ & .00 & $-.06(.08)$ & -.02 \\
\hline Family income & $-.06(.03)$ & $-.06^{*}$ & $-.23(.09)$ & $-.07^{* *}$ & $-.28(.10)$ & $-.07^{* *}$ \\
\hline$\Delta R^{2}$ & \multicolumn{2}{|c|}{$.030^{* * *}$} & \multicolumn{2}{|c|}{$.016^{* * *}$} & \multicolumn{2}{|c|}{$.021^{* * *}$} \\
\hline \multicolumn{7}{|l|}{ Step 2} \\
\hline Emotionality & $.05(.01)$ & $.12^{* * *}$ & $.41(.04)$ & $.28^{* * *}$ & $.46(.05)$ & $.26^{* * *}$ \\
\hline Activity & $.06(.01)$ & $.13^{* * *}$ & $.06(.05)$ & .04 & $.12(.05)$ & $.06^{*}$ \\
\hline Sociability & $-.02(.01)$ & $-.09^{* *}$ & $-.03(.03)$ & -.03 & $-.05(.03)$ & -.05 \\
\hline MR & $-.04(.01)$ & $-.11^{* * *}$ & $-.14(.03)$ & $-.14^{* * *}$ & $-.18(.03)$ & $-.14^{* * *}$ \\
\hline$\Delta R^{2}$ & \multicolumn{2}{|c|}{$.050^{* * *}$} & \multicolumn{2}{|c|}{$.118^{* * *}$} & \multicolumn{2}{|c|}{$.114^{* * *}$} \\
\hline \multicolumn{7}{|l|}{ Step 3} \\
\hline Emotionality $\times \mathrm{MR}$ & $.00(.00)$ & .01 & $-.02(.01)$ & $-.07^{* *}$ & $-.02(.01)$ & $-.06^{*}$ \\
\hline Activity $\times$ MR & $.00(.00)$ & .03 & $.01(.01)$ & .03 & $.01(.01)$ & .03 \\
\hline Sociability $\times$ MR & $.00(.00)$ & .00 & $.00(.01)$ & .01 & $.00(.01)$ & .01 \\
\hline$\Delta R^{2}$ & \multicolumn{2}{|c|}{.001} & \multicolumn{2}{|c|}{$.007^{* *}$} & \multicolumn{2}{|c|}{$.005^{*}$} \\
\hline
\end{tabular}

Note. $N=1,438 . \mathrm{MR}=$ maternal responsiveness.

${ }^{*} p<.05{ }^{* *} p<.01$. ${ }^{* * *} p<.001$.

반응성을 경험하며, 이후 5세에 모든 유형의 외현화 및 내재 화 문제를 많이 나타냈다는 것을 의미한다. 활동성 기질은 어 머니 반응성 및 모든 내재화 영역과 유의한 부적상관 $(r s=-.21$ $\sim-.07, p s<.01)$ 을 나타냈으나, 외현화 영역에서는 주의집중 하고만 유의한 정적상관 $(r=.08, p<.01)$ 을 보였다. 이는 3 세에 높은 활동성 기질을 지닌 유아일수록 높은 어머니 반응성을 경험하고, 이후 5세에 모든 내재화 문제는 적게 나타낸 반면, 주의집중 문제는 많이 나타냈음을 의미한다. 사회성 기질은 어머니 반응성과 유의한 정적상관을, 문제행동의 모든 영역들 과는 유의한 부적상관( $r s=-.35 \sim-.07, p s<.01)$ 을 나타냈다. 이 는 3 세에 높은 사회성 기질을 지닌 유아일수록 높은 어머니 반 응성을 경험하고, 이후 5 세에 모든 유형의 외현화 문제와 내재 화 문제를 적게 나타냈음을 의미한다.

\section{3 세의 기질 특성과 어머니 반응성이 5 세의 문제행동 영역에 미치는 영향}

Time 1 의 유아 기질과 어머니 반응성이 Time 2 의 유아 문제행 동 영역에 미치는 독립적 영향력과 상호작용 효과를 알아보 기 위해 일련의 위계적 회귀분석을 실시하였다. 첫 번째 분석
은 외현화 문제 총점 및 그 하위영역에 대해 실시되었고, 두 번 째 분석은 내재화 문제 총점 및 그 하위영역에 대해 실시되었 다. 모든 회귀분석에서는 1단계에 통제변인인 유아 성별, 어머 니 학력, 가구소득이 투입되었고, 2 단계에 정서성 기질, 활동 성 기질, 사회성 기질, 그리고 어머니 반응성이 함께 투입되었 다. 3 단계에는 각 기질 차원과 어머니 반응성 간 상호작용 항 들이 투입되었다. 이 때 상호작용 항의 다중공선성 문제를 예 방하기 위해 모든 예측변인들을 평균중심화 한 후, 각 기질 변 인과 어머니 반응성 변인을 서로 곱해 상호작용 항을 산출하 였다(Aiken \& West, 1991).

3 세의 기질 특성과 어머니 반응성이 5 세의 외 현화 문제행동 영역에 미치는 영향

유아의 외현화 문제행동 총점 및 그 하위척도 점수(주의집중 문제, 공격행동) 각각에 대해 일련의 위계적 회귀분석을 실시 하였다. 그 결과는 Table 2 와 같다.

모든 회귀분석 결과를 종합하면 다음과 같다. 첫째, 모든 분 석에서 1 단계에 투입된 통제변인 대다수가 유의하였다. 둘째, 2 단계에 투입된 기질 차원들 중 정서성 기질은 외현화 총점 및 
Table 3

Regression Model Predicting Children's Internalizing Behaviors

\begin{tabular}{|c|c|c|c|c|c|c|c|c|c|c|}
\hline \multirow[b]{2}{*}{ Variable } & \multicolumn{2}{|c|}{ Emotional reactivity } & \multicolumn{2}{|c|}{$\begin{array}{l}\text { Anxious/ } \\
\text { Depressive }\end{array}$} & \multicolumn{2}{|c|}{ Somatic complaints } & \multicolumn{2}{|c|}{ Withdrawn } & \multicolumn{2}{|c|}{$\begin{array}{c}\text { Overall } \\
\text { internalizing }\end{array}$} \\
\hline & $B(S E B)$ & $\beta$ & $B(S E B)$ & $\beta$ & $B(S E B)$ & $\beta$ & $B(S E B)$ & $\beta$ & $B(S E B)$ & $\beta$ \\
\hline Sex & $.00(.11)$ & .00 & $.06(.11)$ & .01 & $.00(.09)$ & .00 & $.15(.09)$ & .04 & $.21(.33)$ & .02 \\
\hline Maternal education & $.06(.03)$ & .05 & $.08(.03)$ & $.07^{* *}$ & $-.00(.02)$ & -.00 & $.00(.02)$ & .00 & $.14(.09)$ & .04 \\
\hline$\Delta R^{2}$ & \multicolumn{2}{|c|}{$.010^{* *}$} & \multicolumn{2}{|c|}{$.016^{* * *}$} & \multicolumn{2}{|c|}{$.005^{*}$} & \multicolumn{2}{|c|}{$.006^{*}$} & \multicolumn{2}{|c|}{$.013^{* * *}$} \\
\hline \multicolumn{11}{|l|}{ Step 2} \\
\hline Emotionality & $.16(.02)$ & $.23^{* * *}$ & $.12(.02)$ & $.18^{* * *}$ & $.07(.02)$ & $.13^{* * *}$ & $.05(.01)$ & $.10^{* * *}$ & $.41(.05)$ & $.20^{* * *}$ \\
\hline Activity & $.01(.02)$ & .01 & $.01(.02)$ & .02 & $-.02(.02)$ & -.04 & $-.03(.02)$ & -.05 & $-.03(.06)$ & -.01 \\
\hline Sociability & $-.07(.01)$ & $-.17^{* * *}$ & $-.09(.01)$ & $-.22^{* * *}$ & $-.01(.01)$ & -.05 & $-.09(.01)$ & $-.28^{* * *}$ & $-.26(.03)$ & $-.22^{* * *}$ \\
\hline \multicolumn{11}{|l|}{ Step 3} \\
\hline Emotionality $\times$ MR & $-.01(.00)$ & $-.06^{*}$ & $.00(.00)$ & .01 & $-.00(.00)$ & -.04 & $-.01(.00)$ & -.05 & $-.02(.01)$ & -.04 \\
\hline Activity $\times \mathrm{MR}$ & $.00(.00)$ & .03 & $.00(.00)$ & .00 & $-.00(.00)$ & -.02 & $.01(.00)$ & $.08^{* *}$ & $.01(.01)$ & .03 \\
\hline Sociability $\times$ MR & $.00(.00)$ & .02 & $.00(.00)$ & -.00 & $.00(.00)$ & -.01 & $.00(.00)$ & .00 & $.00(.01)$ & .01 \\
\hline$\Delta R^{2}$ & \multicolumn{2}{|c|}{$.006^{*}$} & \multicolumn{2}{|c|}{.000} & \multicolumn{2}{|c|}{.002} & \multicolumn{2}{|c|}{$.010^{* *}$} & \multicolumn{2}{|c|}{.003} \\
\hline
\end{tabular}

Note. $N=1,438 . \mathrm{MR}=$ maternal responsiveness.

${ }^{*} p<.05 .{ }^{* *} p<.01 .{ }^{* * *} p<.001$.

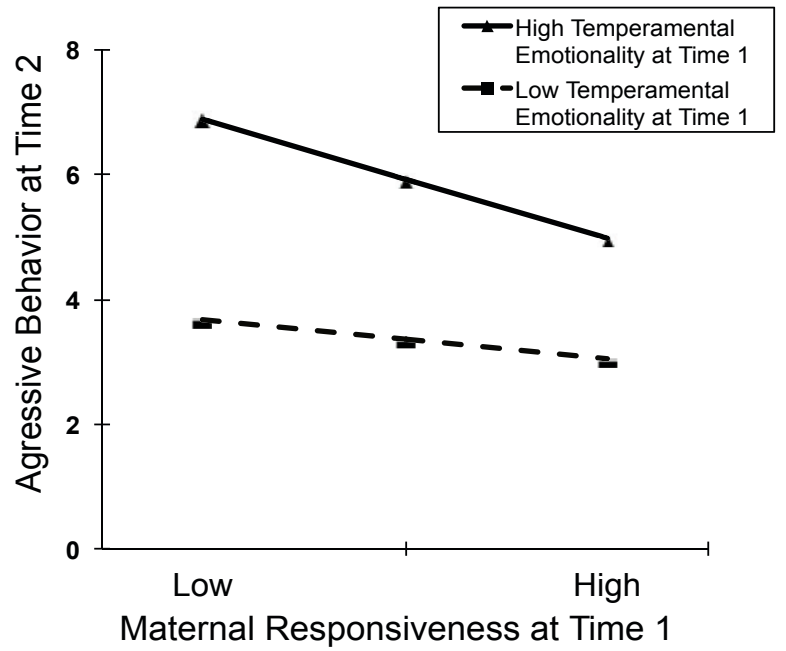

Figure 1. Predicting aggressive behavior problems from interactions between children's temperamental emotionality and maternal responsiveness.

하위 척도 모두에서 독립적인 예측력을 나타낸 반면( $\beta s=.12$ .28, ps <.001), 활동성 기질은 외현화 총점 및 주의집중 문제 에 대해서만 예측력을 나타냈고(각각 $\beta=.06, p<.05 ; \beta=.13$, $p<.001)$, 사회성 기질은 오직 주의집중 문제에 대해서만 예측 력을 나타냈다 $(\beta=-.09, p<.01)$. 어머니 반응성은 모든 외현화 척도에서 고유한 예측력을 보였다 $(\beta s=-.14 \sim-.11, p s<.001)$. 기질 차원들과 어머니 반응성을 예측변인으로 하는 2 단계 회 귀모델의 설명력은 .001 수준에서 모두 유의한 것으로 나타났 다. 그러나 그 설명력 정도는 외현화 총점 $\left(\Delta R^{2}=.114\right)$ 및 공격 행동 $\left(\Delta R^{2}=.118\right)$ 변량에 대한 설명력이 주의집중 문제 변량에 대한 설명력 $\left(\Delta R^{2}=.050\right)$ 에 비해 더 컸다. 마지막 3단계에 투입 된 상호작용 항들은 외현화 총점 및 공격행동에 대해서만 일 부 상호작용(즉, 정서성 기질 $\times$ 어머니 반응성)이 각각 .05와 .01 수준에서 추가적인 예측력을 나타냈다.

어머니 반응성과 공격행동 간 관계에 대한 정서성 기질의 조절효과를 검증하기 위해, Aiken과 West (1991)에 따라 높은 정서성 기질 $(+1 S D)$ 과 낮은 정서성 기질 $(-1 S D)$ 에 대한 각각의 기울기를 구하고 이를 그래프로 나타낸 후, 각 기울기의 유의 성을 통계적으로 검증하였다. Figure 1을 보면, 어머니 반응성 과 유아 공격행동 간 부적관계의 정도는 유아의 정서성 기질 이 높은 경우가 낮은 경우보다 강하다는 것을 알 수 있다. 이에 대한 통계적 검증 결과도 높은 정서성 기질의 경우 높은 어머 


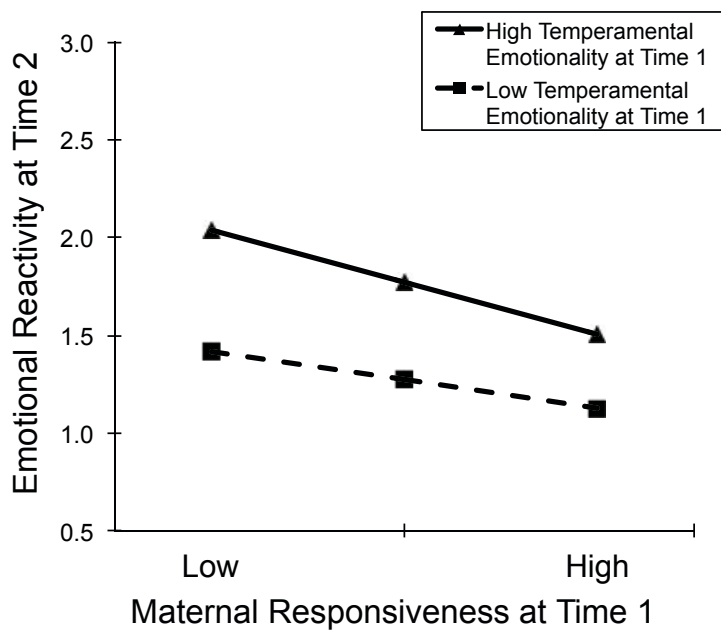

Figure 2. Predicting emotional reactivity problems from interactions between children's temperamental emotionality and maternal responsiveness.

니 반응성이 낮은 공격행동을 유의하게 예측했지만 $(\beta=-.21$, $p<.001)$, 낮은 정서성 기질의 경우에는 공격행동에 대한 어머 니 반응성의 예측력은 유의수준에 도달하지 못했다 $(\beta=-.07$, $p=.05)$. 이러한 결과는 Time 1 에 높은 정서성 기질을 지닌 유 아들이 그렇지 않은 유아들에 비해 Time 2 의 공격행동 발달과 관련하여 어머니의 높은 반응성으로부터 보다 큰 혜택을 받았 다는 것을 의미한다.

3 세의 기질 특성과 어머니 반응성이 5 세의 내 재화 문제행동 영역에 미치는 영향

유아의 내재화 문제행동 총점 및 그 하위척도 점수(정서적 반 응성, 불안/우울, 신체증상, 위축)에 대한 위계적 회귀분석 결 과가 Table 3에 제시되어 있다. 일련의 회귀분석 결과를 종합 하면, 먼저 모든 분석결과에서 1단계에 투입된 통제변인들 중 에는 주로 가구소득이 유의하였다. 2 단계에 투입된 기질 차원 들 중 정서성 기질은 모든 내재화 척도에서 독립적인 예측력 을 나타낸 반면( $\beta s=.10 \sim .23, p s<.001)$, 활동성 기질은 그 어 떠한 독립적 예측력도 나타내지 못했다. 사회성 기질은 대부 분의 내재화 척도에서 독립적 예측력을 나타냈다( $\beta s=-.28 \sim$ -.17 , ps <.001). 어머니 반응성은 모든 내재화 척도에서 고유 한 예측력을 나타냈다( $\beta s=-.11 \sim-.07, p s<.05) .2$ 단계 회귀모 델의 설명력은 모두 .001 수준에서 유의하였으나, 그 설명력 정도는 신체증상 변량에 대해서가 약 $4 \%$ 로 가장 작고, 내재화 총점 및 나머지 하위영역에 대해서는 11-15\%로 비슷하였다.

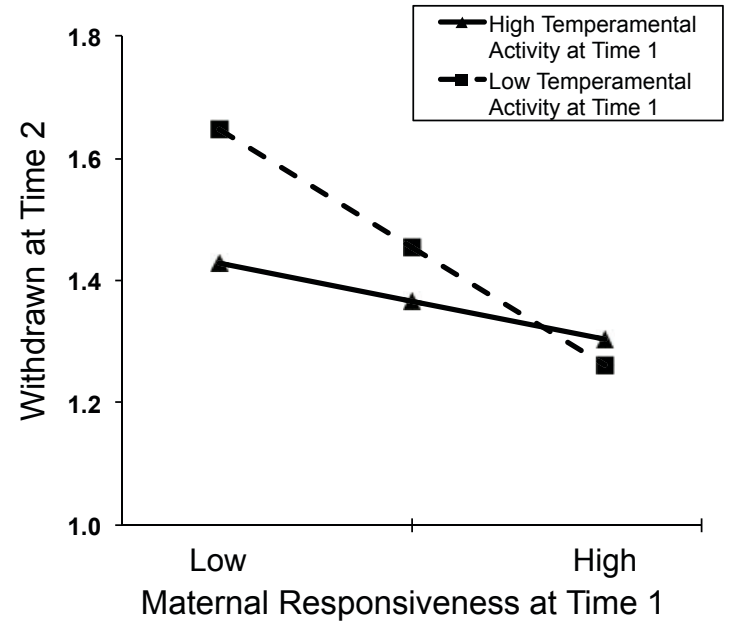

Figure 3. Predicting withdrawn problems from interactions between children's temperamental activity and maternal responsiveness.

마지막 3단계에 투입된 상호작용 항들은 내재화 총점에 대해 서는 그 어떤 상호작용도 유의하지 않았으나, 일부 하위 척도 에 대해서는 일부 상호작용이 유의한 것으로 나타났다. 즉 정 서적 반응성에서는 '정서성 기질 $\times$ 어머니 반응성' $(\beta=-.06, p<$ $.05)$ 이, 위축에서는 '활동성 기질 $\times$ 어머니 반응성' $(\beta=.08, p<$ $.01)$ 이 추가적인 예측력을 나타냈다.

끝으로, 정서적 반응성과 위축에서 나타난 기질의 조절효 과를 살펴보기 위해 높은 기질( $+1 S D)$ 과 낮은 기질( $-1 S D)$ 에 대 한 각각의 기울기를 구해 그래프로 나타내고, 그 기울기의 유 의성을 통계적으로 검증하였다(Aiken \& West, 1991). Figure 2 는 정서적 반응성에서 나타난 정서성 기질의 조절효과를 나타 낸 그래프다. 어머니 반응성과 유아의 정서적 반응성 간 부적 관계의 정도는 정서성 기질이 높은 경우가 낮은 경우보다 강 했다. 통계적 검증 결과, 높은 정서성 기질의 경우 높은 어머 니 반응성은 낮은 정서적 반응성을 유의하게 예측하였다 $(\beta=$ $-.12, p<.001)$ 반면에 낮은 정서성 기질의 경우 정서적 반응성 에 대한 어머니 반응성의 예측력은 유의하지 않았다 $(\beta=-.01$, $p>$ >10). 이러한 결과는 Time 1 에 높은 정서성 기질을 지닌 유 아들이 그렇지 않은 유아들에 비해 Time 2의 정서적 반응 문 제의 발달과 관련하여 어머니의 높은 반응성으로부터 보다 큰 혜택을 받았음을 의미한다.

Figure 3은 위축에서 나타난 활동성 기질의 조절효과를 나 타낸 것으로, 어머니 반응성과 유아의 위축 간 부적관계의 정 도는 유아의 활동성 기질이 낮은 경우가 높은 경우보다 강했 다. 이에 대한 통계적 검증 결과, 낮은 활동성 기질의 경우 높 
은 어머니 반응성이 낮은 위축을 유의하게 예측한 반면( $\beta=$ $-.19, p<.001)$, 높은 활동성 기질의 경우에는 위축에 대한 어 머니 반응성의 예측력이 유의하지 않은 것으로 나타났다 $(\beta=$ $-.04, p>.10)$. 이러한 결과는 Time 1 에 낮은 활동성 기질을 지 닌 유아들이 그렇지 않은 유아들에 비해 Time 2 의 위축 문제 의 발달과 관련하여 어머니의 높은 반응성으로부터 보다 큰 혜택을 받았다는 것을 의미한다.

\section{논의 및 결론}

본 연구의 목적은 유아기 동안 초기의 서로 다른 기질 특성과 반응적 양육경험이 이후 문제행동의 넓은 요인(외현화, 내재 화)과 좁은 요인(주의집중 문제, 공격행동, 정서적 반응성, 불 안/우울, 신체증상, 위축)에 걸쳐 어떠한 영향력을 나타내는지 살펴보고자 하는 것이었다. 이를 위해 3 세 유아의 정서성 기 질, 활동성 기질, 사회성 기질, 그리고 어머니 반응성이 이후 5 세에 나타나는 다양한 유형의 문제행동 발달에 각각 독립적인 예측력을 지니는지 살펴보았다. 그리고 어머니 반응성과 문제 행동 발달 간 종단관계가 유아가 지닌 기질 특성의 수준에 따 라 다르게 나타나는지 살펴보았다. 연구의 주요 결과를 요약 하고 논의하면 다음과 같다.

먼저 5세의 외현화 문제행동 발달과 관련하여, 본 연구의 결과는 3 세의 기질 특성 중 정서성 기질이 일관적으로 가장 강 한 예측력을 지닌다는 것을 보여주었다. 정서성 기질은 유아 가 부정적인 정서를 경험하는 정도를 일컫는다. 선행 종단연 구(Gartstein et al., 2012; Y. S. Kim \& Kwak, 2016)에서 보고된 바와 같이 발달 초기의 부정적 정서 기질은 이후 높은 수준의 전반적 외현화 문제뿐 아니라 그 하위영역 문제 모두(주의집 중 문제, 공격행동)를 예측하는 주된 위험요인으로 나타났다. 전반적 외현화 문제와 일부 하위영역에서 나타난 활동성 기질 의 예측력도, 높은 활동성 기질을 지닌 유아들은 행동 통제력 의 부족으로 인해 외현화 문제를 보다 많이 겪을 수 있다는 기 존의 주장(Mathiesen \& Prior, 2006)과 대체로 일치한다. 한편 본 연구에서는 사회성 기질의 예측력이 주의집중 문제에 대 해서만 나타났는데, 이는 높은 사회성 기질이 모든 유형의 문 제행동을 감소시키는 보호요인이라고 알려진 것과 다소 일치 하지 않는다. 어머니 반응성과 관련해서는, 3 세 시기 높은 어 머니 반응성이 이후 모든 유형의 외현화 문제를 감소시키는 데 기여한다는 것을 보여주었다. 이는 생의 초기 따뜻하고 반 응적인 양육이 아동의 적응적 발달을 돕는 결정적 요인이라는
것을 다시 한 번 확인시켜 준 결과다. 본 연구는 또한 어머니 의 높은 반응성이 전반적 외현화 문제 및 공격행동 발달에 미 치는 개선효과가 높은 정서성 기질을 지닌 유아들의 경우 그 렇지 않은 유아들보다 훨씬 크다는 것을 보여주었다. 이는 전 반적 외현화 문제의 발달에 대한 영아기 기질과 어머니 양육 행동의 상호작용 효과를 보고한 선행연구(Belsky et al., 1998; Stright et al., 2008)와 유사한 결과다. 국내 연구로는 S. C. Kim 과 Kwak (2011)이 학동기 아동의 학교 적응에 대한 부정적 반 응성 기질과 어머니의 긍정적 양육 간 상호작용 효과를 보고 한 바 있다.

다음으로, 내재화 문제행동의 발달과 관련해서는 3 세의 높 은 정서성 기질이 5 세에 나타나는 전반적 내재화 문제와 그 하 위영역 문제 모두를 증가시키지만, 반대로 높은 사회성 기질 은 모든 유형의 문제를 감소시킨다는 것을 보여주었다. 이러 한 결과는 유아기 높은 정서성 기질이 외현화 문제뿐 아니라 내재화 문제도 증가시키는 위험요인인 반면 사회성 기질은 그 러한 문제를 감소시키는 보호요인이라는 것을 의미한다. 외현 화 문제에서와 마찬가지로, 어머니 반응성은 모든 유형의 내 재화 문제를 감소시키는데 기여하였다. 연구는 또한 일부 내 재화 문제(정서적 반응성, 위축)의 발달과 관련하여, 취약한 기질 특성(높은 정서성, 낮은 활동성)을 지닌 유아들은 그렇지 않은 유아들에 비해 어머니의 높은 반응성으로부터 보다 큰 혜택을 받을 수 있다는 것을 보여주었다. 관련연구가 비교적 제한적이지만, 선행연구에서도 유아기 전반적 내재화 문제의 발달과 관련하여 기질과 부모양육의 상호작용 효과가 보고되 었다(Putnam et al., 2002). 참고로, 내재화 문제는 행동 접근체 계(approach system)의 결여 즉, 낮은 활동성과 밀접히 관련된 다. 따라서 높은 활동성 기질은 외현화 문제와 관련해서는 유 아가 행동 표출을 통제하는데 어려움을 야기할 수 있지만, 내 재화 문제와 관련해서는 기분이 가라앉거나 위축되지 않도록 보호한다고 볼 수 있다(Gartstein et al., 2012). 본 연구에서 활동 성 기질은 독립적으로는 그 어떤 내재화 문제에도 영향을 미 치지 못했지만 어머니 반응성과 상호작용해서 위축 발달에 영 향을 미칠 수 있는 것으로 나타났다.

기대했던 바와 같이, 기질 안정성이 가장 높다고 알려진 3 세의 서로 다른 기질 특성은 5 세에 나타나는 모든 유형의 외 현화 문제 및 내재화 문제에 대해 대체로 고유한 예측력을 나 타냈으며, 어머니 반응성 또한 모든 유형의 문제행동을 감소 시키는데 기여하는 것으로 나타났다. 특히 정서성 기질은 일 관적으로 강한 예측력을 보였는데, 일부 문제행동 영역에서는 어머니 반응성과의 상호작용을 통해서도 영향력을 행사할 수 
있는 것으로 나타났다. 활동성 기질의 예측력은 주로 외현화 문제에 대해서만 나타났고, 내재화 문제에서는 나타나지 않았 다. 그러나 이러한 주효과의 부재가 활동성 기질이 내재화 문제 행동 발달에서 중요한 역할을 하지 않는다는 것을 의미하지는 않는다. 문제행동의 발달은 기질과 부모양육 간 상호작용에도 크게 의존하기 때문이다(Belsky, 2005). 실제로 일부 내재화 영역 에서 나타난 활동성과 어머니 반응성의 상호작용 효과는 활동 성 기질이 내재화 문제행동 발달에 영향력을 행사하기 위해서 는 어머니 반응성에 보다 크게 의존한다는 것을 의미한다.

한편, 본 연구가 일부 문제행동 영역에서 정서성 기질과 활 동성 기질의 조절효과를 보여주는 데에는 성공하였지만, 사 회성 기질의 조절효과는 보여주지 못했다. 높은 사회성 기질 은 대부분의 문제행동 영역에서 보호요인으로서의 주효과를 나타냈지만 어머니 반응성과 상호작용해서 영향을 미치지는 않았다. 게다가 정서성 기질과 활동성 기질의 조절효과도 전 체 문제행동 영역 중 절반정도에서만 나타났다. 나머지 영역 에서 기질의 조절효과가 나타나지 않은 원인에 대해서는 명확 히 설명하기 어렵다. 그러나 가능한 원인으로는 척도의 신뢰 도나 타당도 문제 때문일 수 있고, 혹은 연구대상 유아들의 연 령 때문일 수도 있다. 특히 후자와 관련해서, Gallagher (2002) 와 Kochanska (1997)는 발달 초기에는 기질과 부모양육의 주 효과가 보다 뚜렷하고, 이후 아동이 나이가 들면서 다양한 상 호작용 효과가 보다 흔하게 발견될 수 있다고 제안하였다. 서 론에 기술하였듯이, 본 연구의 기질이 측정된 3세 시기는 기질 안정성이 정점에 도달하는 시기다. 이후로는 기질이 중간정도 (modest)의 안정성을 보인다는 사실은 유아가 나이가 들수록 환경으로 인한 기질의 변화 가능성도 증가한다는 것을 의미한 다(Roberts \& DelVecchio, 2000). 그러나 상호작용 효과와 연령 간 관계에 대한 이러한 제한적인 추론이 지지되기 위해서는 보다 많은 유아기 종단자료가 필요하다.

비록 일부 영역에서 기질의 조절효과가 나타나지 않았지 만, 나머지 영역들에서 나타난 조절효과의 의미까지 줄어드는 것은 아니다. 서로 다른 문제행동 영역에서 나타난 기질과 어 머니 반응성의 상호작용 효과는 일련의 통제변인뿐 아니라 모 든 독립변인들(정서성 기질, 활동성 기질, 사회성 기질, 어머 니 반응성)의 강력한 주효과를 통제하고 난 후에도 추가적으 로 유의하게 나타난 것이었다. 이는 유아기 초반의 기질과 부 모양육이 각각의 고유한 영향력 이상으로, 이후에 나타나는 다양한 유형의 문제행동과 관련하여 보다 나은 발달성과를 야 기하기 위해 서로가 서로에게 크게 의존한다는 것을 보여주는 결과다.
연구결과가 유아기 문제행동의 발달과 관련하여 제공하는 시사점은 다음과 같다. 첫째, 어린 유아들은 그들이 지닌 기질 특성으로 인해 이후 서로 다른 문제행동 발달경로를 밟게 될 수 있다는 것이다. 따라서 부모나 교사들은 유아가 나타내는 문제행동이 단지 학습만으로 야기된 결과는 아니라는 점을 주 지하고 개별 아동의 특성에 대한 보다 수용적인 태도를 지녀 야 할 것이다. 둘째, 유아기 초반 어머니의 높은 반응성은 이후 모든 유형의 문제행동을 감소시키는데 의미 있는 기여를 할 수 있다는 것이다. 어머니의 양육태도가 영유아기 동안 비교 적 안정적으로 나타난다는 선행연구 결과(NICHD Early Child Care Research Network, 1999)는 생의 초기 적절한 부모교육의 필요성을 더욱 높인다고 할 수 있다. 셋째, 무엇보다 이러한 반 응적 부모양육이 문제행동 발달에 미치는 개선효과는 기질적 으로 취약한 유아에게 훨씬 현저할 수 있다는 것이다. 기질적 으로 취약한 유아들일수록 내적 갈등을 극복하고 적응적 발달 을 이루기 위해 보다 고군분투할 것이며 외부의 도움을 보다 절실히 필요로 할 것이다. 그리고 이들에게 부모의 긍정적 양 육태도는 보다 큰 혜택을 줄 수 있을 것이다. 따라서 부모교육 의 초점은 부모가 유아의 부정적 기질 특성으로 인해 겪을 수 있는 어려움을 극복하고 보다 수용적인 태도를 기를 수 있도 록 돕는 것에 초점을 맞출 필요가 있다. 이와 더불어 유아의 기 질 취약성과 관련된 핵심측면(예: 자기조절 부족)에 대한 직접 적인 중재나 훈련 또한 의미 있는 성과를 거둘 수 있을 것이다. 최근 이러한 중재 노력이 일부 연구자들(McClowry, Rodriguez, $\&$ Koslowitz, 2008)을 중심으로 이루어지고 있다는 사실은 매 우 고무적이라 할 수 있다.

본 연구의 제한점을 밝히고, 후속 연구를 위해 제언하면 다음과 같다. 먼저, 연구에 사용된 주요 변인들에 대한 자료 는 모두 부모응답에 기초한 자료였기 때문에 변인들 간 관계 가 과대추정 되었을 수 있다. 따라서 연구결과가 다른 유형의 척도(예: 관찰, 수행검사)를 통해 수집된 자료로도 반복 검증 될 필요가 있다. 연구의 또 다른 제한점은 문제행동의 일부 하 위척도(예: 신체증상)에서 나타난 신뢰도 문제와 관련된다. Rescorla 등(2011)은 CBCL 1.5-5의 모든 하위척도가 높은 검 사-재검사 신뢰도와 준거타당도를 지닌다는 점을 감안하면 일부 하위척도의 낮은 $\alpha$ 값이 곧 낮은 신뢰도를 의미하는 것은 아니라고 주장하였다. 그러나 국내에서는 관련 자료가 아직 제한적이기 때문에 이러한 결론은 유보적인 것으로 보이며, 해당 하위척도에 대한 결과해석에도 주의가 요구된다고 하겠 다. 추가적으로, 본 연구는 부모양육 변인으로 어머니 반응성 만 살펴보았기 때문에 부모양육의 또 다른 주요 측면인 통제 
(예: 심리적 통제)나 아버지 양육으로 야기될 수 있는 효과는 함께 다루지 못했다. 후속 연구는 이를 고려하여 부모양육 효 과를 보다 통합적으로 밝힐 수 있을 것이다.

이러한 제한점에도 불구하고 본 연구는 다음과 같은 의 의를 지닌다고 할 수 있다. 첫째, 이론적 가정(Belsky, 2005; Rothbart \& Bates, 2006)에 기초하여 유아기 기질과 부모양육 의 상호작용 효과에 대한 증거를 제공했다는 것이다. 둘째, 대 규모 종단자료를 바탕으로 그동안 관련정보가 비교적 제한적 이었던 유아기 기질과 부모양육, 문제행동 발달 간 관계에 대 한 정보를 제공했다는 것이다. 셋째, 문제행동 변인으로 넓은 요인과 더불어 좁은 요인 척도를 함께 살펴봄으로써 유아기 다양한 문제행동 발달에 대한 기존의 이해를 보다 확장시켰다 는 것이다.

결론적으로, 본 연구는 2 년이라는 시간차에도 불구하고 유 아기 초반의 기질 특성과 어머니의 반응적인 양육태도가 후반 에 나타나는 다양한 유형의 문제행동 발달에 대해 각각 독립 적인 예측력을 지님과 동시에 서로 상호작용해서도 영향을 미 칠 수 있다는 것을 보여주었다. 특히 상호작용 효과는 아동의 기질 특성과 부모양육이 서로 함께 아동의 발달 경로를 의미 있게 수정할 수 있다는 기존의 이론적 가정과 경험자료를 뒷 받침하는 증거를 제공했다고 할 수 있다. 이러한 연구결과가 유아의 적응적 발달을 도울 수 있는 중재계획을 수립하는 데 에 유용한 정보를 제공할 수 있기를 기대한다.

\section{Conflict of Interest}

No potential conflict of interest relevant to this article was reported.

\section{References}

\section{In English}

Achenbach, T. M., Ivanova, M. Y., Rescorla, L. A., Turner, L. V., \& Althoff, R. R. (2016). Internalizing/externalizing problems: Review and recommendations for clinical and research applications. Journal of the American Academy of Child \& Adolescent Psychiatry, 55(8), 647-656. doi:10.1016/ j.jaac.2016.05.012

Aiken, L. S., \& West, S. G. (1991). Multiple regression: Testing and interpreting interactions. Newbury Park, CA: Sage.
Baron, R. M., \& Kenny, D. A. (1986). The moderator-mediator distinction in social psychological research: Conceptual, strategic, and statistical considerations. Journal of Personality and Social Psychology, 51(6), 1173-1182. doi:10.1037/00223514.51.6.1173

Belsky, J. (2005). Differential susceptibility to rearing influence: An evolutionary hypothesis and some evidence. In B. J. Ellis \& D. F. Bjorklund (Eds.), Origins of the social mind: Evolutionary psychology and child development (pp.139-163). New York: Guilford Press.

Belsky, J., Hsieh, K. H., \& Crnic, K. (1998). Mothering, fathering, and infant negativity as antecedents of boys' externalizing problems and inhibition at age 3 years: Differential susceptibility to rearing experience? Development and Psychopathology, 10(2), 301-319.

Bornstein, M. H., Tamis-LeMonda, C. S., Pascual, L., Haynes, O. M., Painter, K. M., Galperin, C. Z., \& Pecheux, M. G. (1996). Ideas about parenting in Argentina, France, and the United States, International Journal of Behavioral Development, 19(2), 347-367. doi:10.1177/016502549601900207

Bradley, R. H., \& Corwyn, R. F. (2008). Infant temperament, parenting, and externalizing behavior in first grade: A test of the differential susceptibility hypothesis. Journal of Child Psychology and Psychiatry, 49(2), 124-131. doi:10.1111/ j.1469-7610.2007.01829.x

Buss, A. H., \& Plomin, R. (1984). Temperament: Early developing personality traits. Hillsdale, NJ: Erlbaum.

Campbell, S. B. (1995). Behavior problems in preschool children: A review of recent research. Journal of Child Psychology and Psychiatry, 36(1), 113-149. doi:10.1111/j.1469-7610.1995. tb01657.x

Campbell, S. B., Spieker, S., Burchinal, M., Poe, M. D., \& NICHD Early Child Care Research Network. (2006). Trajectories of aggression from toddlerhood to age 9 predict academic and social functioning through age 12 . Journal of Child Psychology and Psychiatry, 47(8), 791-800. doi:10.1111/j.1469-7610.2006.01636.x

Carlson, E. A. (1998). A prospective longitudinal study of attachment disorganization/disorientation. Child Development, 69(4), 1107-1128. doi:10.1111/j.1467-8624.1998.tb06163.x

DeVellis, R. F. (1991). Scale development: Theory and applications. Newbury Park, NJ: Sage Publications.

Gallagher, K. C. (2002). Does child temperament moderate the influence of parenting on adjustment? Developmental Review, 22(4), 623-643.

Gartstein, M. A., Putnam, S. P., \& Rothbart, M. K. (2012). Etiology of preschool behavior problems: Contributions of temperament attributes in early childhood. Infant Mental Health Journal, 33(2), 197-211. doi:10.1002/imhj.21312

Goldsmith, H. H., Buss, A. H., Plomin, R., Rothbart, M. 
K., Thomas, A., Chess, S., . . McCall, R. B. (1987). Roundtable: What is temperament? Four approaches. Child Development, 58(2), 505-529. Retrieved from http://www. jstor.org/stable/ 1130527

Kochanska, G. (1997). Multiple pathways to conscience for children with different temperaments: From toddlerhood to age 5. Developmental Psychology, 33(2), 228-240. doi:10.1037/0012-1649.33.2.228

Maccoby, E. E., \& Martin, J. A. (1983). Socialization in the context of the family: Parent-child interaction. In P. H. Mussen (Series Ed.) \& M. E. Hetherington (Ed.), Handbook of Child Psychology: Vol. 4. Socialization, personality, and social development (pp. 1-101). New York, NY: Wiley.

Mathiesen, K. S., \& Prior, M. (2006). The impact of temperament factors and family functioning on resilience processes from infancy to school age. European Journal of Developmental Psychology, 3(4), 357-387. doi:10.1080/17405620600557797

McClowry, S. G., Rodriguez, E. T., \& Koslowitz, R. (2008). Temperament-based intervention: Re-examining goodness of fit. International Journal of Developmental Science, 2(1-2), 120-135. doi:10.3233/DEV-2008-21208

Mervielde, I., \& Asendorpf, J. B. (2000). Variable-centered versus person-centered approaches to childhood personality. In S. E. Hampson (Ed.), Advances in personality psychology (Vol. 1, pp. 37-76). Philadelphia: Taylor \& Francis.

Mesman, J., Bongers, I. L., \& Koot, H. M. (2001). Preschool developmental pathways to preadolescent internalizing and externalizing problems. Journal of Child Psychology and Psychiatry, 42(5), 679-689. doi:10.1111/1469-7610.00763

Moffitt, T. E. (1990). Juvenile delinquency and attention deficit disorder: Boys' developmental trajectories from age 3 to age 15. Child Development, 61(3), 893-910. doi:10.1111/ j.1467-8624.1990.tb02830.x

NICHD Early Child Care Research Network. (1999). Chronicity of maternal depressive symptoms, maternal sensitivity, and child functioning at 36 months. Developmental Psychology, 35(5), 1297-1310. doi:10.1037/0012-1649.35.5.1297

Nigg, J. T. (2006). Temperament and developmental psychopathology. Journal of Child Psychology and Psychiatry, 47(3-4), 395-422. doi:10.1111/j.1469-7610.2006.01612.x

Nunnally, J. C., \& Bernstein, I. H. (1994). Psychometric theory (3rd ed.). New York: McGraw-Hill.

Putnam, S., Sanson, A. V., \& Rothbart, M. K. (2002). Child temperament and parenting. In M. H. Bornstein (Ed.), Handbook of Parenting: Vol 1. Children and parenting (2nd ed., pp. 255-277). Mahwah, NJ: Lawrence Erlbaum Associates.

Rescorla, L. A., Achenbach, T. M., Ivanova, M. Y., Harder, V. S., Otten, L., Bilenberg, N., . . . Verhulst, F. C. (2011).
International comparisons of behavioral and emotional problems in preschool children: Parents' reports from 24 societies. Journal of Clinical Child \& Adolescent Psychology, 40(3), 456-467. doi:10.1080/15374416.2011.563472

Roberts, B. W., \& DelVecchio, W. F. (2000). The rank-order consistency of personality traits from childhood to old age: A quantitative review of longitudinal studies. Psychological Bulletin, 126(1), 3-25. doi:10.1037/0033-2909.126.1.3

Rothbart, M. K. (1989). Temperament in childhood: A framework. In G. Kohnstamm, J. Bates, \& M. K. Rothbart (Eds.), Temperament in childhood (pp. 59-73). New York: Wiley.

Rothbart, M. K., \& Bates, J. E. (2006). Temperament. In W. Damon, R. Lerner, \& N. Eisenberg (Eds.), Handbook of Child Psychology: Vol. 3. Social, emotional, and personality development (6th ed., pp. 99-166). New York: Wiley.

Sameroff, A. J. (1975). Early influences on development: Fact or fancy? Merrill-Palmer Quarterly of Behavior and Development, 21(4), 267-294. Retrieved from http://www. jstor.org/stable/23083878

Smith, J., \& Prior, M. (1995). Temperament and stress resilience in school-age children: A within-families study. Journal of the American Academy of Child \& Adolescent Psychiatry, 34(2), 168-179. doi:10.1097/00004583-199502000-00012

Stright, A. D., Gallagher, K. C., \& Kelley, K. (2008). Infant temperament moderates relations between maternal parenting in early childhood and children's adjustment in first grade. Child Development, 79(1), 186-200. doi:10.1111/j.1467-8624.2007.01119.x

Thomas, A., \& Chess, S. (1977). Temperament and development. Oxford: Brunner/Mazel.

\section{In Korean}

Doh, H.-S., Shin, N., Park, B.-K., Kim, M.-J., \& Kim, H.-I. (2014). The effects of mothers' depression and parenting behavior on preschoolers' externalizing problem behaviors. Korean Journal of Child Studies, 35(4), 179-198. Retrieved from http://www.riss.kr/link?id=A102954462

Han, J., \& Lee, J. S. (2016). The effects of preschooler temperament and maternal postnatal depression, depression, and parenting stress on preschooler externalizing problem. Korean Journal of Child Studies, 37(6), 69-82. doi:10.5723/ kjcs.2016.37.6.69

Kang, J. H., \& Oh, K. J. (2011). Gender differences in the effects of preschoolers' age, temperament and parenting for internalizing and externalizing problems. The Korean Journal of Woman Psychology, 16(1), 1-21. Retrieved from http://www.riss.kr/link?id=A100632932

Kim, S. C., \& Kwak, K. J. (2011). The mediating role of child's temperament on early school adjustment and 
mother's parenting attitudes: On the negative reactivity of temperament. The Korean Journal of Developmental Psychology, 24(2), 155-171. Retrieved from http://www.riss. $\mathrm{kr} / \mathrm{link}$ ?id=A100634137

Kim, Y. S., \& Kwak, K. J. (2016). Effect of developmental change of infant's temperament on preschoolers' externalizing behaviors. The Korean Journal of Developmental Psychology, 29(3), 95-111. Retrieved from http://www.riss.kr/ link?id=A102055769

Lee, K. S., Shin, Y. J., Chun, Y. J., \& Park, J. A. (2004). The characteristics of behavior problem among young children in Korea. The Korean Journal of Developmental Psychology, 17(4), 53-73. Retrieved from http://www.riss.kr/ link?id=A100634466
Oh, K. J., \& Kim, Y. A. (2008). The Korean version of the Child Behavior Checklist (CBCL) for ages 1.5-5 manual. Seoul: Huno.

\section{ORCID}

Jinna Chung http://orcid.org/0000-0002-3290-1327
Received February 28, 2017

Revision received April 4, 2017

Accepted April 12, 2017 